\title{
Factors affecting trace metal accumulation by estuarine oysters Crassostrea virginica*
}

\author{
H. L. Phelps ${ }^{1}$, D. A. Wright ${ }^{2} \&$ J. A. Mihursky ${ }^{2}$
}

\begin{abstract}
${ }^{1}$ University of the District of Columbia, Department of Biology, 4200 Connecticut Ave, Washington, D.C. 20008, USA ${ }^{2}$ University of Maryland, Center for Environmental and Estuarine Studies, Chesapeake Biological Laboratory, Solomons, Maryland 10688, USA
\end{abstract}

\begin{abstract}
Copper, zinc, cadmium and silver analyses were made of groups of ca 34 individual oysters taken from 13 oyster bars in the mid-Chesapeake Bay region on the east coast of the United States. Data are described for the years 1978, 1979 and 1981. Sampling stations were chosen to represent high and low salinity regimes as well as sites of potentially differing metal input. Metal concentrations were determined on a wet-weight basis and were found to be largely negatively correlated with body weight and with salinity. Data were entered in a multiple regression program which included body weight and salinity as independent variables, and regression equations were used to normalize the metal concentrations. Data indicated localized copper concentration in oysters close to 2 electricity generating stations, although at 1 of these sites the high values could be explained in terms of the body weight/salinity model. High metal concentrations were also indicated at an oyster bar having stunted animals. Results indicated that the use of oysters to map trace metal input to an estuary can be complicated by extraneous factors such as salinity, but that useful information may still be obtained after normalization to size and salinity. Year-to-year comparison between these data and earlier data indicate that correction for salinity may have to be reset from year to year.
\end{abstract}

\section{INTRODUCTION}

Many filtering bivalves are good bioaccumulators of trace metals and act as natural integrators of these and other pollutants over time. Bivalve molluscs are now used world-wide as indicators of trace metal pollution (Bayne 1978, Goldberg et al. 1978). The ubiquitousness of the genus Mytilus has led to its widespread use as a biomonitor in marine systems (e.g. deWolf 1975, Phillips 1976a, b, 1977, Karbe et al. 1977, Davies \& Pirie 1978, Harris et al. 1979, Murray 1982). Although many of these programs have been successful in identifying point sources of contaminants, a number of investigations have identified various accessory environmental parameters affecting trace metal concentration by biological material (quite apart from metal input to the aquatic environment). Unlike pesticides and herbicides there is comparatively little evidence implicating changes in run-off as a source of variability in metal levels in aquatic biota (Phillips 1980). However, Frazier (1976) reported a spring cadmium peak in

- Contribution No. 1586 of the University of Maryland Center for Environmental and Estuarine Studies
Chesapeake Bay oysters in 1972, which he attributed to a metal pulse flushed into the Bay by tropical storm Agnes.

Following the work of Boyden $(1974,1977)$ and others (Phillips 1976a, Manly \& George 1977. Davies \& Pirie 1978, Harris et al. 1979, Cooper et al. 1982, Popham \& D'Auria 1983) it is apparent that animal size (not always equated with age) is an important factor influencing trace metal concentration in several species, although size/metal relations are not always consistent from one investigation to another. Within estuarine environments a variety of molluscs have been used as bioindicators in place of Mytilus species and, in many cases, an apparent 'salinity effect' on body burdens of various trace metals has been noted (Huggett et al. 1973, Phillips 1977). Seasonal variation has also been attributed variously to salinity changes, as well as growth and regression of germinal tissue, somatic tissue and food storage products (Phillips 1980). Such seasonal variability has led Phillips (1980) to advocate a standardized collection period in monitoring programs, and the above examples indicate that salinity and animal size must often be taken into account when comparing samples collected from 
different sites or at different times. Sample size is often given insufficient consideration (Gordon et al. 1980) and where outliers are retained in the data set, collections must be sufficiently large to minimize their effect.

The Chesapeake Bay system is the largest and most productive estuary in the United States; however until recently it has been the subject of very few biomonitoring studies. Recent declines in some finfish catches and in the oyster fishery have prompted renewed interest in anthropogenic contamination of the estuary. The US Environmental Protection Agency-Chesapeake Bay Program (USEPA-CBP) and related studies (Helz et al. 1981, Kingston et al. 1982) have indicated significant trace metal input from the Susquehanna River and industrialized areas such as Baltimore Harbor and the Elizabeth River. Helz (1976) estimated that $51 \%$ of copper and $74 \%$ of lead reaching the northern part of the Chesapeake Bay may be anthropogenic in origin.

Unfortunately, there is remarkably little published work concerning metal levels in biota from this region. Two exceptions are the works of Huggett et al. (1973) and Frazier $(1975,1976,1979)$, both measuring trace metals in the oyster Crassostrea virginica. Huggett et al. (1973) found exceptionally high levels of copper and zinc in oysters from the Elizabeth River and Hampton Roads areas at the south of the Bay. Frazier (1979) reported a 4 yr time course of cadmium data using genetically homogeneous brood stock oysters set in a comparatively uncontaminated river (Rhode R.) in the central Chesapeake Bay. C. virginica is one of the most widely distributed bivalve molluscs in the Bay. This distribution, together with its exceptional bioaccumulatory capacity (Shuster \& Pringle 1969) make it a very suitable animal for biomonitoring. In addition the oyster represents a valuable food resource, and concern for tissue quality has led to a widespread survey of trace metals in $C$. virginica in central and northern parts of the Chesapeake Bay by the Maryland Department of Health (Eisenberg \& Topping 1981). This survey contains extensive data for $\mathrm{Cu}, \mathrm{Zn}, \mathrm{Pb}, \mathrm{Hg}, \mathrm{Cd}$ and $\mathrm{Cr}$ in oysters since 1976 and As data from 1977. All analyses are based on composite samples of about 10 individuals collected from sites throughout the whole central and northem Bay area.

Proposed dredge spoil dumping from heavily contaminated Baltimore harbor has culminated in the construction of a nearby diked dredge-spoil containment facility at Hart and Miller Islands close to the Back River estuary, and this in turn has prompted biomonitoring efforts using tray-set oysters by Cronin et al. (1974) and Wright \& Striegel (1984).

From 1974-1981 copper and zinc were monitored in oysters from the Calvert Cliffs (CC) area close to a nuclear power plant together with a more northerly reference site, Scientist Cliffs (SC) (Phelps 1984).
Changes in tissue metal concentrations at both these sites indicated a requirement for looking at the larger pattern of fluctuations in body burdens over the whole mid-Bay area and in 1978 the survey was extended to 13 collection sites in the central Bay area and Patuxent River, selected to include a range of salinity and contaminated and uncontaminated sites. Metal analyses were extended to cadmium and silver. This effort comprised large numbers of individual analyses, which enabled a detailed appraisal of inherent variability associated with the material (Wright \& Phelps, unpubl.).

This paper presents data on 4 metals $(\mathrm{Cu}, \mathrm{Zn}, \mathrm{Ag}$, $\mathrm{Cd}$ ) from the above survey and attempts to place these data within the context of other Chesapeake biomonitoring efforts. In doing so we have attempted to rationalize a number of variables having possible effects on values obtained, including in particular animal size and salinity, apart from possible differential metal input.

\section{METHODS AND MATERIALS}

Oysters were collected by oyster dredge from University of Maryland's, Center for Environmental and Estuarine Studies research vessels. Sampling stations and other sites referred to in this work are shown in Fig. 1. Sampling stations were deliberately chosen for their differing characteristics with regard to both metal input and salinity. The sampling periods were chosen as $2 \mathrm{~d}$ cruises in the same week (early June) in 1978, 1979 and 1981 in order to minimize possible seasonal effects (Roosenburg 1969, Frazier 1979, Boyden \& Phillips 1981). Collections constituted a representative sample of the size range of individuals found at the respective oyster bar and no special effort was made to sample animals of a particular size. Each collection represented at least 30 to 34 individuals and the analytical strategy was to identify the most important independent variables affecting metal concentrations in this large data set. Oysters were scrubbed, shucked and individuals were blotted, weighed and digested in 10 to $20 \mathrm{ml}$ redistilled nitric acid heated to $70^{\circ} \mathrm{C}$. Digests were filtered through pre-washed glass fiber filters before analysis. Analyses were made using flame atomic absorption spectroscopy or by AAS following graphite furnace atomization. Four metals were included in the present study. In addition to copper and zinc concentrations which were obtained from at least 13 stations in 1978, 1979 and 1981, cadmium and silver data was analyzed in most samples collected in 1978 and 1979.

A single salinity measurement was made at each oyster bar at the time of collection. While it is appreci- 


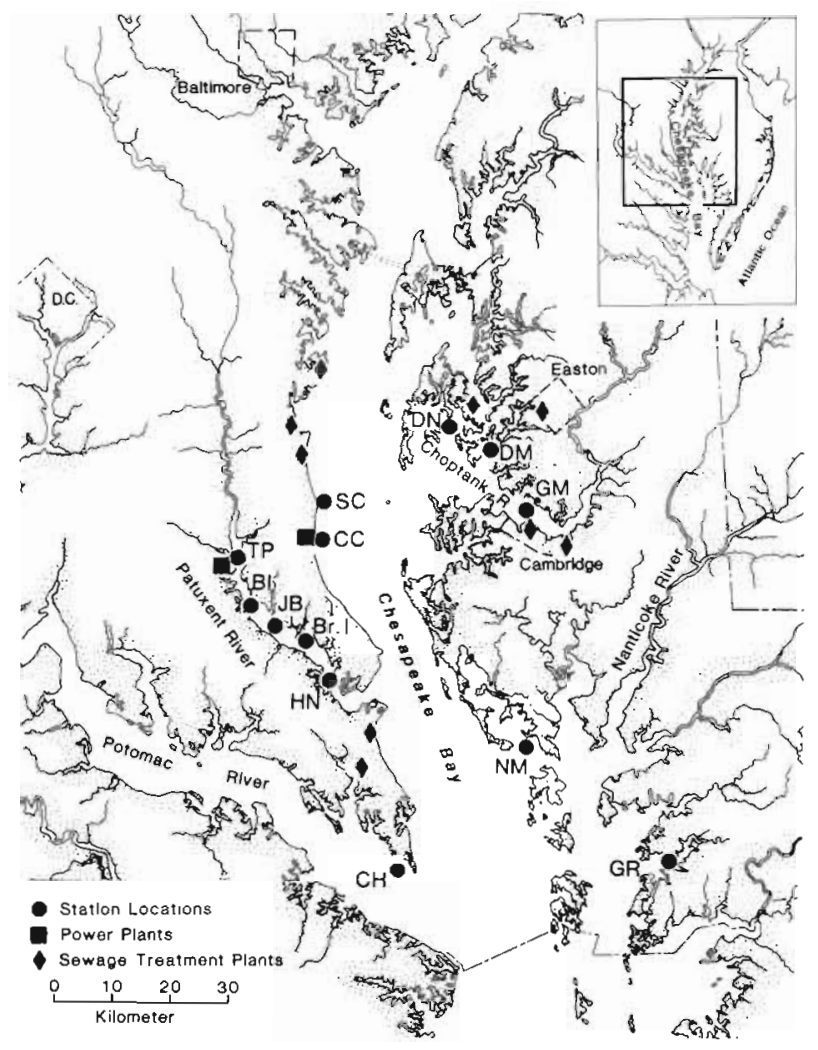

Fig. 1. Map of central Chesapeake Bay showing locations of oyster bars sampled during early June, 1978, 1979 and 1981 TP: Teague Point, downstream of Chalk Point power plant BI: Buzzard's Island; JB: Jack's Bay; BrI: Broome's Island HN: Hawk's Nest, mouth of Patuxent River; SC: Scientist Cliffs; CC: Calvert Cliffs near Calvert Cliffs Power Plant; $\mathrm{CH}$ Cornfield Harbor, mouth of Potomac River; DN: Deep NeckBroad Creek; DM: Double Mills; GM: Green Marsh below sewage treatment plant; NM: Norman's Marsh; GR: Great Rock

ated that salinities at these sites fluctuate considerably according to season it is felt that such measurements give an accurate impression of the comparative salinity picture over the whole study area (there is little diurnal range in salinity, Beaven 1960). Such an impression is confirmed by consultation of long-term salinity records, where available, from the Maryland Department of Natural Resources and Chesapeake Biological Laboratory.

\section{RESULTS}

Even in oysters from the same site, zinc and copper concentrations often differed appreciably from year to year (Fig. 2). The same was true of size (Fig. 2). Oysters from Broome's Island in 1979, for example, were twice the weight of those from the previous year and Calvert Cliffs individuals collected in 1981 were half the weight of 1979 specimens. It is not known to what extent this may have been due to our sampling of different size classes in different years or whether differential glycogen or germinal tissue bulk caused significant tissue weight changes from year to year even though sampling was at the same site. Commercial harvesting and state restocking programs may also have affected size distribution from year to year. However, recent evidence suggests that no differing genetic stocks are involved (Newell \& Rainer, unpubl.).

The 1978 data for all 4 metals (Fig. 3 to 6) show the contribution made to the weight vs metal relation by oysters from different bars; sometimes strikingly different contributions may be seen for different sites in relation to overall weight/metal concentration relation (for an alternative method of presentation of similar data, see Popham \& D'Auria 1983). These contributions often differ from metal to metal. For example, most of the high silver values (Fig. 3) are contributed by Green Marsh (GM) and Deep Neck (DN) animals, yet cadmium data from these sites contribute low and moderate values, respectively (Fig. 4). Elevated cadmium levels are mainly found in Teague Point (TP) and Broome's Island (Br. I) oysters. Although most high values for both these metals are contributed by smaller individuals, the situation is complicated by some sites containing almost exclusively small oysters that also have low metal concentrations (e.g. Great Rock (GR), Norman's Marsh (NM).

In general copper and zinc data follow each other quite closely (Fig. 5 and 6) and have several features in common with the silver data. For all 3 metals Deep Neck oysters display a comparatively wide range of concentrations despite their narrow size range. In 1978 the highest zinc values were found in Green Marsh specimens. It is interesting that, in 1979. Deep Neck oysters showed exceptionally high zinc and copper concentrations although they were again lower in 1981 (Fig. 2). In contrast to the Deep Neck site and despite some outliers, Teague Point oysters had a relatively narrow range of copper concentrations. Although a ttest following normalization of these data (after Lobel \& Wright 1983) revealed no significant difference between tissue copper concentrations at these 2 sites, Fig. 5 depicts them to have quite different characteristics. A single site, Green Marsh (Fig. 6), had a bimodal distribution of zinc, although the body size range at this site was unimodal.

Within-site weight metal relations were examined for all 4 metals studied. Metals data were normalized by using the natural logarithm of the metal concentration prior to linear regression vs weight. Cadmium had the most consistent relation between (ln) metal concentration and body wet weight. Fifteen out of the 24 collections analyzed for cadmium had negative correlations at the $5 \%$ level of significance. Ten out of 21 collections analyzed for silver showed significant 


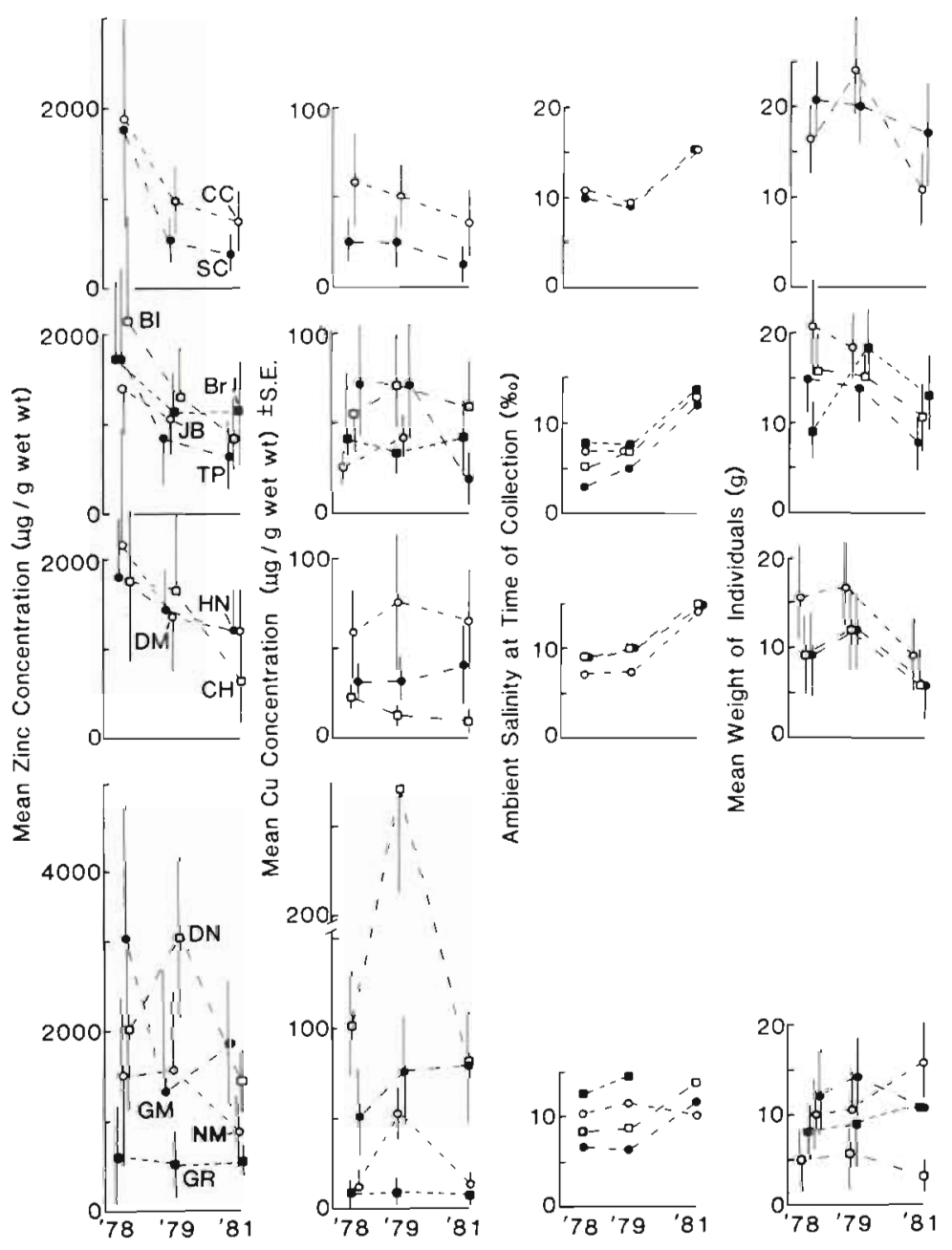

Fig. 2. Summary of zinc, copper, ambient salinity and wet-weight data from 1978, 1979 and 1981 collections. Abbreviations for oyster bars as in Fig. 1. Symbols for wet weight and metal concentration represent mean for each collection \pm 1 standard deviation

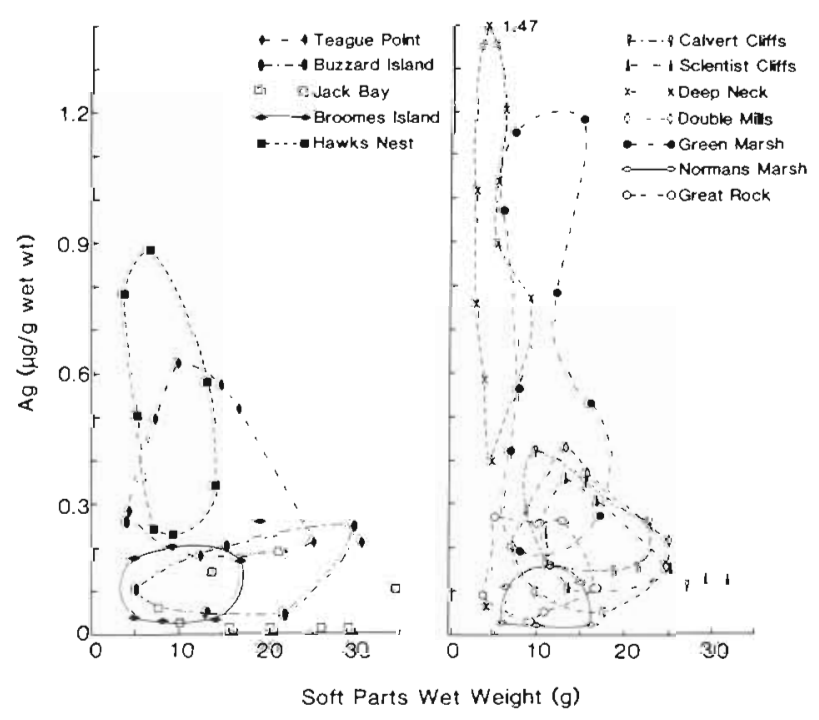

Fig. 3. Relation between silver concentration and soft parts (wet weight) in oysters collected from the central Chesapeake Bay in June 1978. Contours enclose all points except outliers which are indicated as isolated symbols. Some peripheral points are included within each contour (negative) correlation coefficients for In metal $v s$ wet weight. Of 40 collections analyzed for zinc, 7 had a significant negative relation between $\ln$ metal and wet weight and at one site the slope was positive. Of $11 / 40$ significant correlations between $\ln \mathrm{Cu}$ concentration and wet weight 2 were positive and 9 negative. Taken overall, there was strong evidence for a negative relationship between body wet weight and metal concentration (Table 1 ). In Table 2 , linear regression equations are presented for $l n$ metal concentration vs salinity for all annual collections. With 1 exception, there is a highly significant negative correlation between salinity and metal concentration; this is particularly noticeable for copper and cadmium. The 1978 and 1979 data for all metals are plotted in Fig. 7. Although silver data were not significantly correlated with salinity in that year it is perhaps surprising that there was a strong correlation in 1979 for that metal (Fig. 7). Lower correlations for copper and zinc in 1981 compared with earlier years (Table 2) may be due to the unusually narrow (and high) salinity regime which persisted through much of 1981 (Fig. 2). 
Fig. 4. Relation between cadmium concentration and soft parts (wet weight) in oysters collected from the central Chesapeake Bay in June 1978. Symbol notation as in Fig. 3

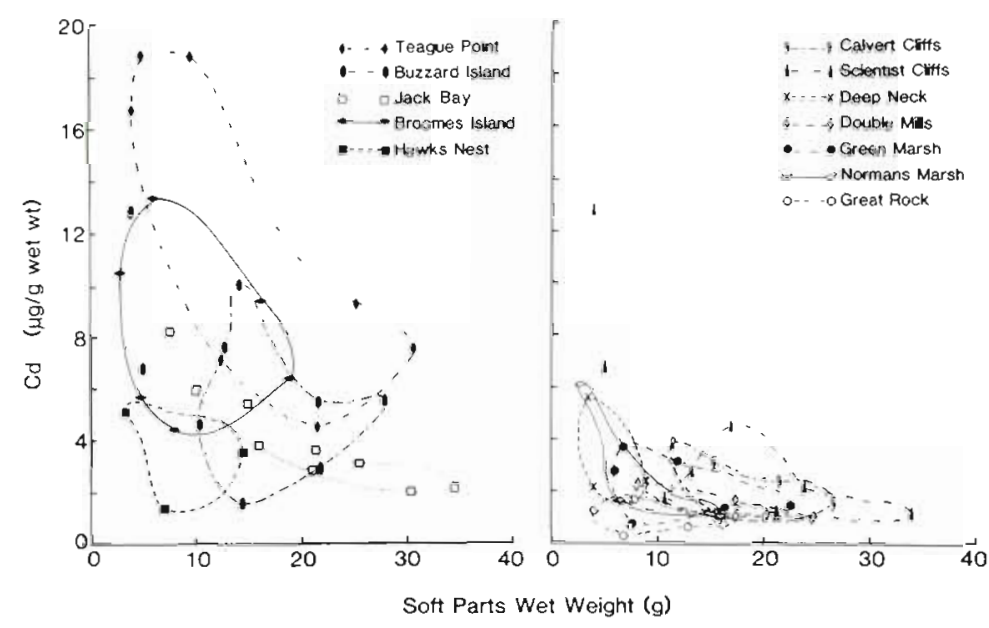

\section{DISCUSSION}

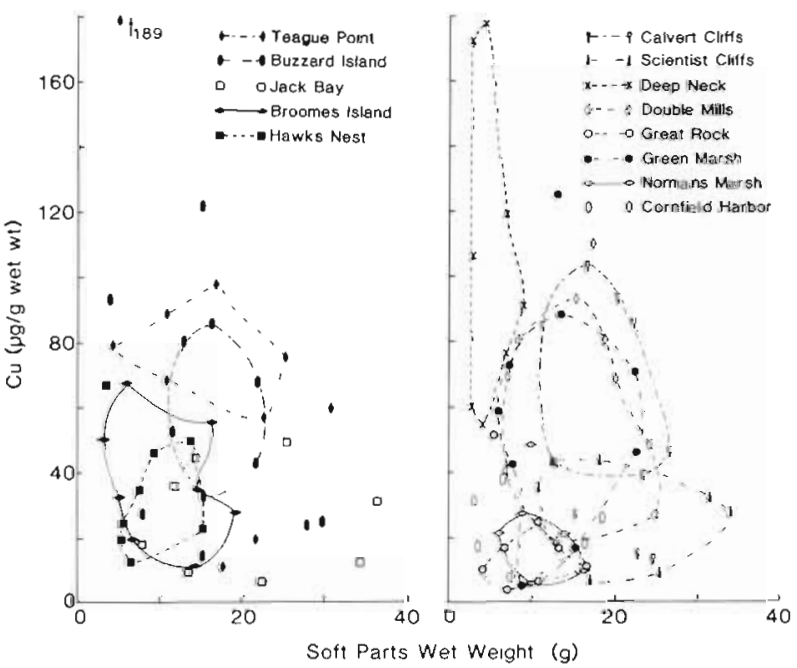

Fig. 5. Relation between copper concentration and soft parts (wet weight) in oysters collected from the central Chesapeake Bay in June 1978. Symbol notation as in Fig. 3
We stress that the ultimate aim of this study was to define differences in oyster metal concentration resulting from possible differences in metal input into the system. In order to compensate for salinity and size/ weight influences already seen, the data were subjected to a multiple regression analysis of wet weight and salinity on In metal concentration (Table 3 ). Salinity and weight data from each site were then substituted in the resultant equation (from each annual collection, Table 3 ) in order to determine empirically the relative influence of these parameters on metal concentration at different sites. Back-transformed values derived from these equations could then be compared with analytically determined mean metal concentrations from each site.

The 1978 copper and zinc values derived from respective multiple regression equations have been compared (Tables 4 and 5) to corresponding metal con-
Fig. 6. Relation between zinc concentration and soft parts (wet weight) in oysters collected from the central Chesapeake Bay in June 1978. Symbol notation as in Fig. 3

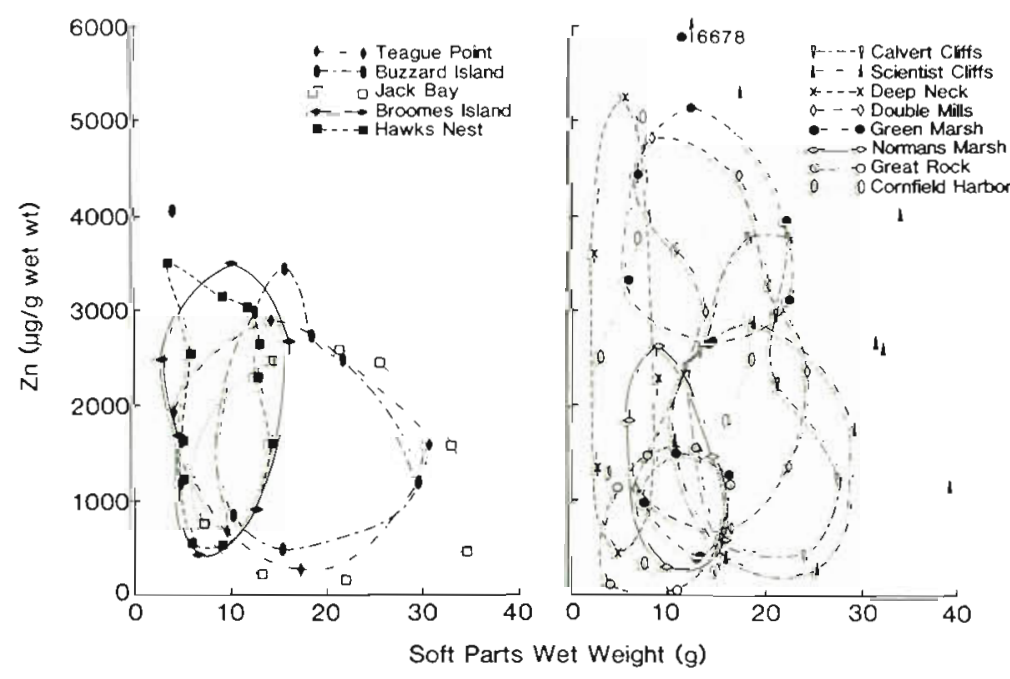


Table 1. 2-variable correlation matrix w wt vs ln oyster metal concentration central Chesapeake Bay (1978-1981)

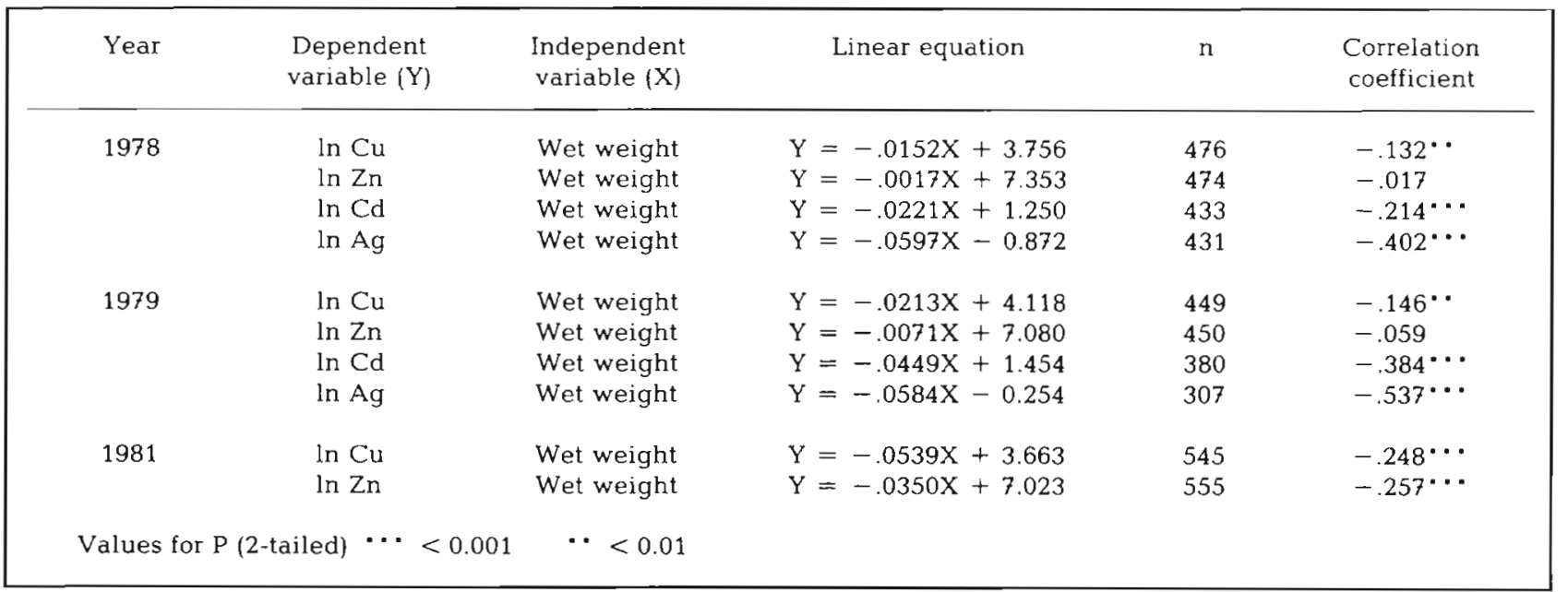

Table 2. 2-variable correlation matrix salinity vs ln oyster metal concentration central Chesapeake Bay (1978-1981)

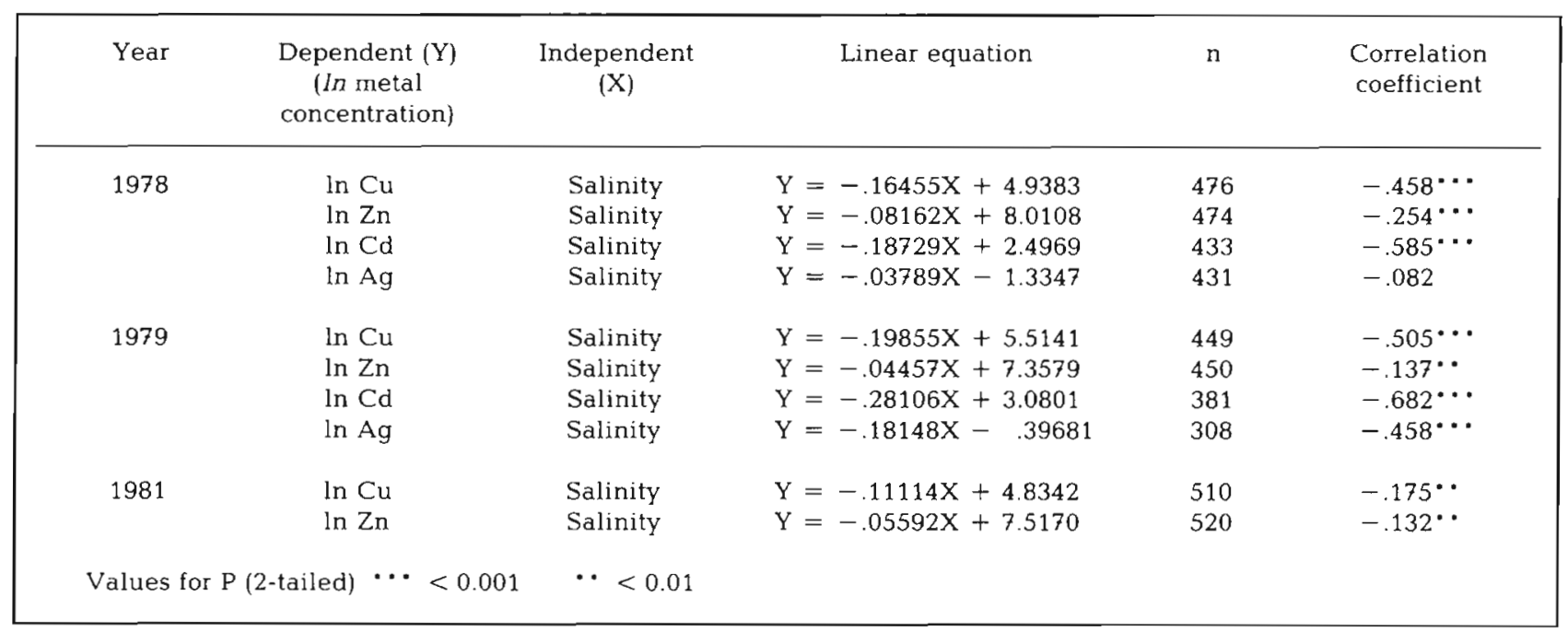

centrations measured at each site. These tables list the degree of increase or decrease represented by analyzed samples compared with 'expected' levels (derived from equations). In essence such a treatment is no different to the normalization procedure advocated by Boyden (1977), Simkiss \& Taylor (1981) and others, except that 2 independent variables are being considered instead of 1 . When the copper data are normalized in this way (Table 4), 2 sites stand out: Calvert Cliffs and Deep Neck. Copper contamination of the former site is not surprising. Possible copper enrichment close to the Calvert Cliffs power plant was, after all, the prime reason for initiating the current project and there is doubtless some localized copper contamination at this site. Of equal interest is the copper concentration at the Teague Point oyster bar where 1978 (and 1979) levels are even higher than those found at Calvert Cliffs. Teague Point, too, is relatively close to the outfall from an electricity generating plant and has been implicated historically as a site of copper contaminated oysters (Roosenburg 1969). The exact status of this site with regard to localized copper contamination is currently being examined. It is clear that, even if this site is locally high in copper, such a condition is exacerbated by the salinity effect and, within the confines of the wet weight/salinity 'model' generated here, the high copper data from Teague Point can be explained by these 2 variables. Since the Teague Point station represented the lowest salinity station, the multiple regression equation was constructed with and without data from this site. The inclusion, or otherwise, of data from Teague Point made little difference to the multiple regression equation and deletion of this station from the regression model, therefore, made no difference to the conclusions reached. Further characterization of possible 


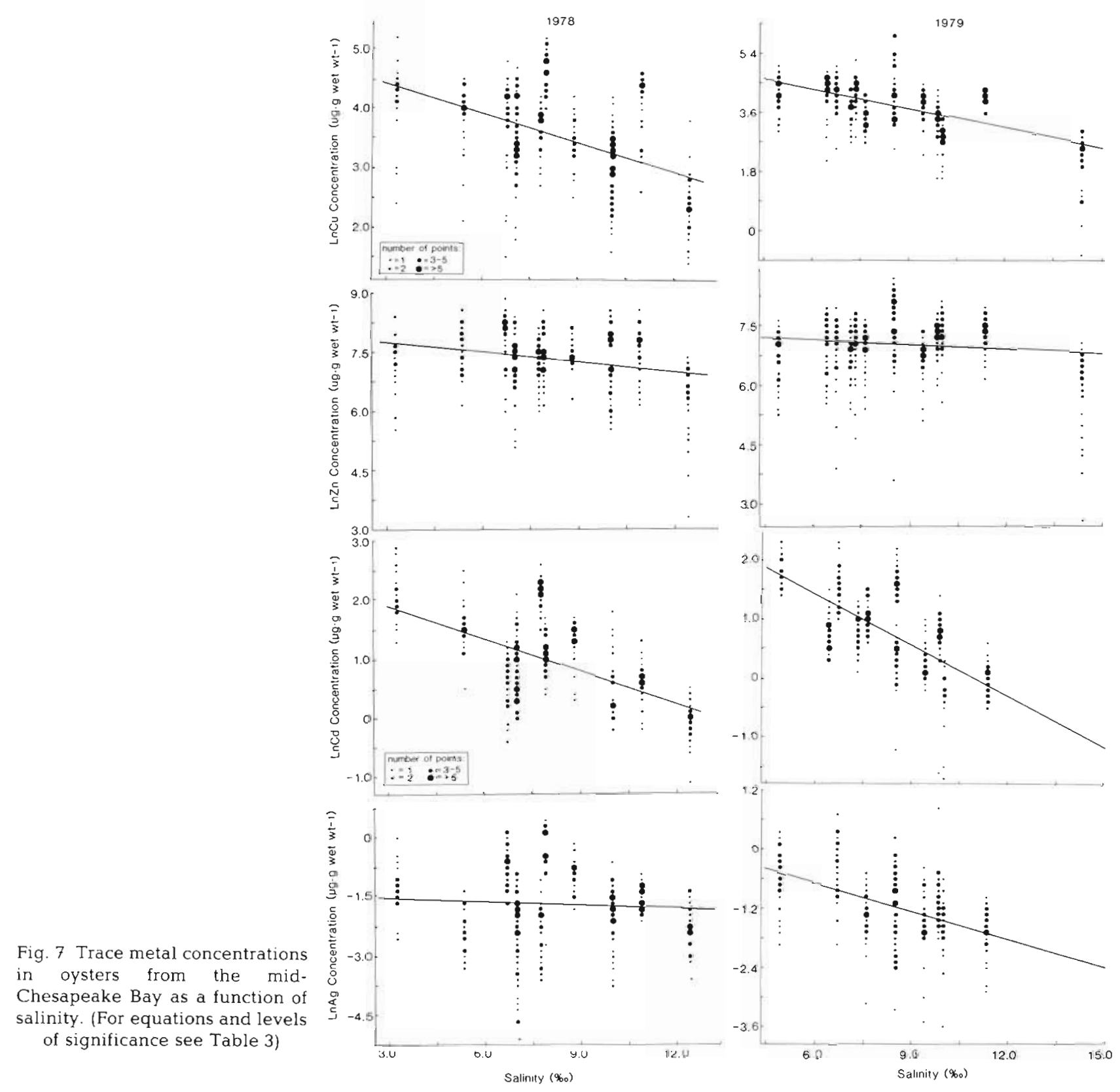

Table 3. Multiple regression equations for wet weight and salinity vs ln oyster metal concentration

\begin{tabular}{|c|c|c|c|c|c|}
\hline Year & 1978 & $\begin{array}{l}\ln [\mathrm{Cu} \text { conc] } \\
\ln [\mathrm{Zn} \text { conc] } \\
\ln [\mathrm{Cd} \text { conc] } \\
\ln [\mathrm{Ag} \text { conc] }\end{array}$ & $\begin{array}{l}=5.32 \\
=8.10 \\
=2.95 \\
=0.362\end{array}$ & $\begin{array}{l}-[\text { Salinity } \times 0.179] \\
-[\text { Salinity } \times 0.0773] \\
-[\text { Salinity } \times 0.197] \\
-[\text { Salinity } \times 0.0594]\end{array}$ & $\begin{array}{l}-[\text { Wet wt. } \times 0.023] \\
-[\text { Wet wt. } \times 0.0055] \\
-[\text { Wet wt. } \times 0.0291] \\
-[\text { Wet wt. } \times 0.059]\end{array}$ \\
\hline & 1979 & $\begin{array}{l}\ln [\mathrm{Cu} \operatorname{con} \mathrm{C}] \\
\ln [\mathrm{Zn} \operatorname{con} \mathrm{C}] \\
\ln [\mathrm{Cd} \operatorname{con} \mathrm{C}] \\
\ln [\mathrm{Ag} \operatorname{con} \mathrm{C}]\end{array}$ & $\begin{array}{l}=6.201 \\
=7.558 \\
=3.61 \\
=1.151\end{array}$ & $\begin{array}{l}-[\text { Salinity } \times 0.216] \\
-[\text { Salinity } \times 0.0495] \\
-[\text { Salinity } \times 0.271] \\
-[\text { Salinity } \times 0.169]\end{array}$ & $\begin{array}{l}-[\text { Wet wt. } \times 0.036] \\
-[\text { Wet wt. } \times 0.104] \\
-[\text { Wet wt. } \times 0.0397] \\
-[\text { Wet wt. } \times 0.0554]\end{array}$ \\
\hline & 1981 & $\begin{array}{l}\ln [\mathrm{Cu} \text { conc }] \\
\ln [\mathrm{Zn} \text { conc }]\end{array}$ & $\begin{array}{l}=5.019 \\
=7.68\end{array}$ & $\begin{array}{l}-[\text { Salinity } \times 0.0919] \\
-[\text { Salinity } \times 0.045]\end{array}$ & $\begin{array}{l}-[\text { Wet wt. } \times 0.0474] \\
-[\text { Wet wt. } \times 0.033]\end{array}$ \\
\hline
\end{tabular}


Table 4. Comparison of size/salinity normalized copper data with measured copper data (1978)

\begin{tabular}{|c|c|c|c|c|}
\hline Station & $\begin{array}{l}\text { Copper concentration } \\
\text { derived from multiple } \\
\text { regression of wet wt. } \\
\& \text { salinity on } \ln \mathrm{Cu} \\
\text { ( } \mu \mathrm{g} \mathrm{g}^{-1} \text { wet weight) }\end{array}$ & $\begin{array}{c}\text { Measured } \\
\text { mean Cu conc. } \\
\text { ( } \mu \mathrm{g} \mathrm{g}^{-1} \text { wet wt.) }\end{array}$ & $\begin{array}{c}\text { Difference between } \\
\text { measured \& 'expected' } \\
\text { Cu conc. } \\
\text { ( } \mu g^{-1} \text { wet weight) }\end{array}$ & $\begin{array}{c}\% \text { Difference between } \\
\text { measured \& 'expected' } \\
\text { Cu conc. }\end{array}$ \\
\hline Calvert Cliffs & 19.1 & 61.8 & +42.7 & +324 \\
\hline Scientist Cliffs & 20.7 & 21.0 & +0.3 & $+\quad 1.4$ \\
\hline Teague' Point & 79.9 & 69.4 & -10.5 & -13.2 \\
\hline Buzzard's Island & 53.6 & 54.6 & +0.9 & $+\quad 1.7$ \\
\hline Broome's Island & 41.1 & 39.4 & -1.7 & -4.1 \\
\hline Jack's Bay & 36.3 & 25.9 & -10.4 & -28.6 \\
\hline Hawk's Nest & 34.2 & 31.8 & -2.4 & -7.2 \\
\hline Cornfield Harbor & 28.0 & 22.2 & -5.7 & -20.6 \\
\hline Deep Neck & 44.5 & 103.2 & +48.7 & +232 \\
\hline Double Mills & 39.7 & 52.9 & +13.2 & +33.3 \\
\hline Green Marsh & 52.7 & 52.2 & $-\quad 0.44$ & $-\quad 0.8$ \\
\hline Norman's Marsh & 26.3 & 16.8 & -9.5 & -36.1 \\
\hline Great Rock & 18.3 & 11.8 & -6.5 & -36.3 \\
\hline
\end{tabular}

Table 5. Comparison of size/salinity normalized zinc data with measured zinc data (1978)

\begin{tabular}{|c|c|c|c|c|}
\hline Station & $\begin{array}{l}\text { Copper concentration } \\
\text { derived from multiple } \\
\text { regression of wet wt. } \\
\& \text { salinity on } \ln \mathrm{Zn} \\
\text { ( } \mathrm{g} \mathrm{g} \mathrm{g}^{-1} \text { wet weight) }\end{array}$ & $\begin{array}{c}\text { Measured } \\
\text { mean } \mathrm{Zn} \text { conc. } \\
\text { ( } \mu \mathrm{g} \mathrm{g} \mathrm{g}^{-1} \text { wet wt.) }\end{array}$ & $\begin{array}{c}\text { Difference between } \\
\text { measured \& 'expected' } \\
\mathrm{Zn} \text { conc. } \\
\left(\mu \mathrm{g} \mathrm{g}^{-1} \text { wet wt.) }\right.\end{array}$ & $\begin{array}{c}\% \text { Difference between } \\
\text { measured \& 'expected' } \\
\text { Zn conc. }\end{array}$ \\
\hline Calvert Cliffs & 1279 & 1999 & +720 & +56 \\
\hline Scientist Cliffs & 1344 & 1845 & +501 & +37 \\
\hline Teague's Point & 2348 & 1733 & -604 & -26 \\
\hline Buzzard's Island & 1986 & 2312 & +326 & +16 \\
\hline Broome's Island & 1715 & 1543 & -172 & -10 \\
\hline Jack's Bay & 1711 & 1828 & -299 & -18 \\
\hline Hawk's Nest & 1586 & 1828 & +242 & +15 \\
\hline Cornfield Harbor & 1450 & 1787 & +337 & +23 \\
\hline Deep Neck & 1742 & 2084 & +342 & +20 \\
\hline Double Mills & 1743 & 2152 & +409 & +23 \\
\hline Green Marsh & 1821 & 2980 & +1159 & +64 \\
\hline Norman's Marsh & 1424 & 1506 & +82 & +6 \\
\hline Great Rock & 1206 & 697 & -509 & -42 \\
\hline
\end{tabular}

sites of copper contamination using metal/metal ratios, as discussed by Simkiss \& Taylor (1981) is currently in progress.

The Deep Neck oyster bar in Broad Creek at the mouth of the Choptank River represents an aberrant site in terms of several high metal concentrations noted (Fig. 2, 3, 5 and 6; Table 4). There are no known sources of trace metals at this site and it is felt that these data may be partly explained by the presence of a number of small, old, stunted oysters in this area. Kennedy and Krantz (unpubl.) have also found that adult oysters from this bar are very significantly smaller than adults collected from 16 other oyster bars in the central Chesapeake Bay region. High metal levels in stunted oysters from the Wando R., South Carolina, were reported by Burrell et al. (1981), although no causal factors were demonstrated. Whatever the cause of stunting at the Deep Neck, Broad Creek bar (at present ambient metals are not implicated), the phenomenon whereby animals of different ages (and therefore different metal exposure) exhibit similar size characteristics is not understood. Despite the fact that 'age normalization' in mussels may be facilitated by the use of allometric ratios (Lobel \& Wright 1982a, b), oysters still remain comparatively difficult to age. A recent study was undertaken to examine the relation between age, stunting and metal accumulation in midChesapeake Bay oysters (Phelps et al. unpubl.). Examination of metal concentrations in normal and stunted oysters of known age (laboratory spawned) found cop- 
per and zinc concentrations in stunted oysters steadily increased with age while in normal oysters metal concentrations decreased with age. The stunted oysters were raised near Deep Neck Broad Creek and assuming similar growth conditions affecting metal accumulation the Deep Neck oysters could be about 8 yr old

The bimodal nature of zinc concentrations in 1978 Green Marsh (GM) specimens (Fig. 6) may have been due to sampling 2 age classes, not separable according to size, and it is interesting that this site apparently represented the most zinc-contaminated site of all during that year, after normalization for weight and salinity (Table 5). Oysters also had significant silver enrichment at that site after salinity/weight normalization and it is speculated that such contamination may be related to the proximity of a sewage treatment plant. Instances such as these indicate that population structure may exert a very subtle influence on size/metal relations and intrasample variability, and may be partially responsible for apparent literature contradictions between size/metal data reported from different locations and even from the same laboratory at different times (e.g. Boyden 1977, Couper et al. 1982, Popham \& D'Auria 1983)

A study such as this and the recent comprehensive survey by Popham \& D'Auria (1983) show that biomonitoring is a complex issue requiring large samples, a long and carefully designed sampling regime and good knowledge of the population dynamics of the organisms sampled. Current data reveal, notwithstanding a substantial 'salinity effect' and a significant inverse relation between body weight and metal concentration, that meaningful data can be obtained from a large-scale monitoring survey, even in a complex estuarine habitat. More detailed mapping would require a more finely tuned sampling regime involving many more localized sites and, from a logistical point of view, use of pooled samples. However, analysis of large numbers of individuals from a variety of sites has emphasized the important salinity influence on trace metal accumulation by oysters in an estuary such as the Chesapeake system. Other studies from this region have confirmed such a salinity effect. Using genetically homogeneous, tray-set oysters Cronin et al. (1974) demonstrated an $80 \%$ difference in copper accumulation associated with a $10 \mathrm{ppt}$ difference in salinity. Their use of young brood stock oysters of similar size also permitted growth data to be incorporated into equations describing copper accumulation (Cronin et al. 1974).

In this study also, copper and zinc concentrations in oysters correlated significantly with salinity read at time of collection (Fig. 8 and 9). When power plant sites and stunted oyster sites were excluded, results were similar to Maryland Department of Health data

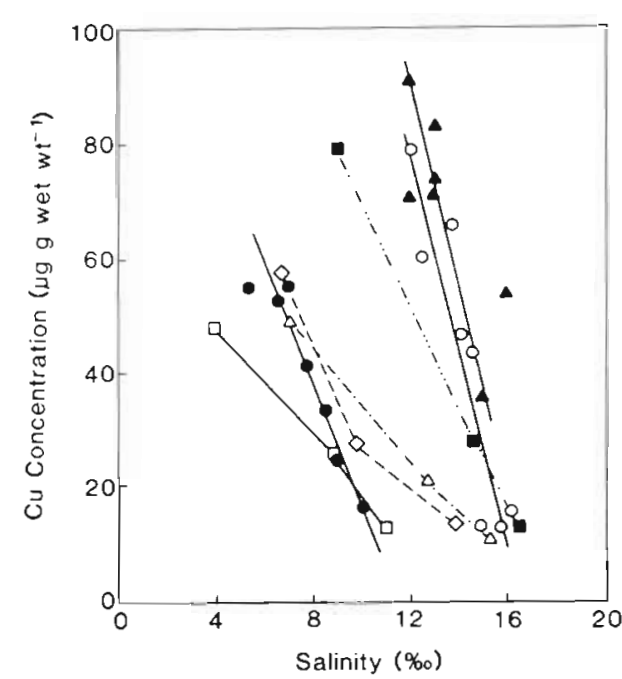

Fig. 8. Relation between copper concentration and salinity derived from 3 Chesapeake Bay studies. Current 1979 and 1981 data $(\bullet, 0)$ included as mean concentrations from each oyster bar; power-plant related sites omitted. $\triangle$ Data from Sinex et al. (1978); $\square, \diamond . \Delta \& \square$ all data from Cronin et al. (1974) (collected in 1970), transformed from dry weight to wet weight basis using a factor of 6.8. $\square$ Jul 1970; $\diamond$ Aug 1970; $\triangle$ Sept $1970 ;$ Oct 1970

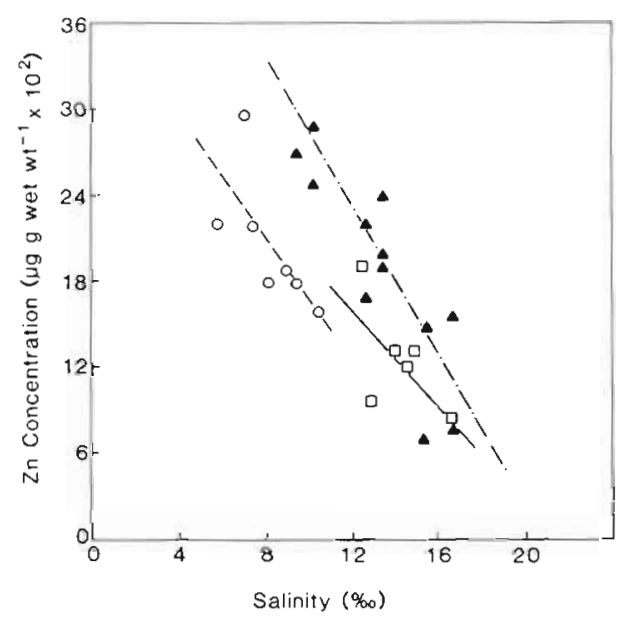

Fig. 9. Relation between zinc concentration and salinity derived from current study: 0 1978; $\square 1981$ (power-plant related sites omitted) and from Sinex et al. (1978) (4)

correlated with yearly average salinity (Sinex et al. pers. comm.). The average correlation of oyster copper concentration with salinity was $16 \mu \mathrm{g}$ copper $\left(\mathrm{g}^{-1}\right.$ oyster $w w t)^{-1}$ (ppt salinity) ${ }^{-1}$; the average correlation of oyster zinc concentration with salinity was $216 \mu \mathrm{g}$ zinc (g oyster $w w t)^{-1}$ (ppt salinity) ${ }^{-1}$. The significant yearly correlation between salinity and copper and zinc concentrations in oysters shifted each year corresponding to change in average yearly salinity. This may indicate the metal storage compartment in oysters is re-set by yearly average salinity. It is obvious therefore that 
correction for salinity must be done on a year-to-year basis.

In Fig. 8 and 9, copper and zinc data from the current study have been compared with other, unpublished information from the Chesapeake Bay region. In doing this we have removed data where obvious metal concentration gradients might be expected (i.e. power plant related data). In all cases there is a strong indication of a salinity effect. This may have several explanations, none of which are mutually exclusive. In view of the relation established between free cupric ion activity and copper accumulation by oysters (Zamuda \& Sunda 1982), it might be speculated that salinity may affect the free ionic activities of these metals and, thus, their bioavailability. Using equations generated by Helz (pers. comm.), it is clear that both zinc and copper activities are inversely related to salinity under conditions of constant total metal concentration, and this may contribute to the salinity effect seen here. However, Zamuda \& Wright (unpubl.) have been able to demonstrate increased copper uptake by oysters under low salinity conditions even when cupric ion activity is held constant using NTA, and so the effect of salinity on metal activity can only be a partial explanation.

Phillips (1977) speculated that the apparent salinity effect seen in metal accumulation by mussels from the straits of Denmark through to the Baltic Sea may have been due to the ingestion of different species of plankton containing different metal concentrations. Such a theory would effectively shift the 'salinity effect' to a lower trophic level and this in turn may have physicochemical (e.g. Sunda et al. 1978) or physiological elements. In higher animals salinity effects on trace metal uptake have been explained by 'passive' osmotic effects (George et al. 1978) and accidental active uptake' (Wright 1977). The likelihood that freshwater sources may also be richer in trace metals (either through industry or through natural run-off) must not be discounted. Sinex (1981) compiled a source inventory for metals entering the Chesapeake system and concludes that the largest overall source of trace elements is the Susquehanna River which enters the Chesapeake Bay at the northernmost end. The fact that this river also represents the single largest freshwater input to the system could also lead to an inverse relation between metal enrichment and salinity. Another significant input from a low saline region is Baltimore Harbor, estimated by Sinex (1981) to account for $24 \%$ of the total input of copper and cadmium to the Bay. In the current study the low salinity stations comprised largely pristine areas, thereby minimizing the importance of land runoff, in whatever form, as an influence on the observed salinity effect.

Acknowledgements. We are grateful to Messrs M. Davis and C. Bostater of Maryland Department of Natural Resources for their valuable assistance in data handling. This work was largely supported by NASA grant NGR 09-050-019 to one of us (HLP).

\section{LITERATURE CITED}

Bayne, B. L. (1978). Mussel watching. Nature, Lond. 275 $87-88$

Beaven, G. F. (1960). Temperature and salinity of surface water at Solomons, Maryland. Chesapeake Sci. 1: 2-11

Boyden, C. R. (1974). Trace element content and body size in molluscs. Nature, Lond. 251: 311-314

Boyden, C. R. (1977). Effect of size upon metal content of shellfish. J. mar. biol. Ass. U.K. 57: 675-714

Boyden, C. R., Phillips, D. J. H. (1981). Seasonal variation of trace elements in oysters and their implications for indicator studies. Mar. Ecol. Prog. Ser. 5: 29-40

Burrell, V. G., Marzi, J. J., Carson, W. Z. (1981). Growth and mortality of two types of seed oysters from the Wando River, South Carolina. J. Shellf. Res. 1: 1-7

Cooper, R. J., Langlois, D., Olley, J. (1982). Heavy metals in Tasmanian shellfish. I. Monitoring heavy metal contamination in the Derwent estuary: use of oysters and mussels. J. appl. Toxicol, 2: 99-109

Cronin, L. E., Pritchard, D. W., Schubel, J. R., Sherk, J. A. (1974). Metals in Baltimore harbor and upper Chesapeake Bay and their accumulation by oysters. Joint report by Chesapeake Bay Institute, Johns Hopkins University and Chesapeake Biological Laboratory, University of Maryland

Davies, I. M., Pirie, J. M. (1978). The mussel Mytilus edulis as a bio-assay organism for mercury in seawater. Mar. Pollut. Bull. 9: 128-132

de Wolf, P. (1975). Mercury content of mussels from west European coasts. Mar. Pollut. Bull. 6: 61-63

Eisenberg, M., Topping, J. J. (1981). Heavy metal, polychlorinated biphenyl and pesticide levels in shellfish and finfish from Maryland waters, 1976-1980. Maryland State Department of Health and Mental Hygiene. Baltimore, Maryland

Frazier, J. M. (1975). The dynamics of metals in the American oyster, Crassostrea virginica. I. Seasonal effects. Chesapeake Sci. 16: 162-171

Frazier, J. M. (1976). The dynamics of metals in the American oyster, Crassostrea virginica. II. Environmental effects. Chesapeake Sci. 17: 188-197

Frazier, J. M. (1979). Bioaccumulation of cadmium in marine organisms. Environ. Hlth Perspect. 28: 75-79

George, S. G., Carpene, E., Coombs, T. L. (1978). The effect of salinity on the uptake of cadmium by the common mussel, Mytilus edulis (L.). In: McLusky, D. S., Berry, A. J. (ed.) Physiology and behaviour of marine organisms. Proc. 12th European Marine Biology Symposium. Pergamon Press, Oxford, p. 189-193

Goldberg, E. D., Bowen, V. T., Farrington, J. W., Harvey, G., Martin, J. H., Parker, P. L., Risebrough, R. W., Robertson, W., Schneider, E., Gamble, E. (1978). The mussel watch. Environ. Conserv. 5: 101-125

Gordon, M., Knauer, G. A., Martin, J. H. (1980). Mytilus californianus as a bioindicator of trace metal pollution: variability and statistical considerations. Mar. Pollut. Bull. 11: $194-198$

Harris, J E., Fabris, G. J., Statham, P. J., Tawfik, F. (1979). Biogeochemistry of selected heavy metals in Western Port, Victoria and use of invertebrates as indicators with emphasis on Mytilus edulis planatus. Austr. J. mar. Freshwat. Res. 30: 159-178 
Helz, G. R. (1976). Trace metal inventory for the northern Chesapeake Bay with emphasis on the influence of man. Geochim. cosmochim. Acta 40: 573-580

Helz, G. R., Sinex, S. A., Setlock, G. H., Cantillo, A. Y. (1981). Chesapeake Bay sediment trace elements. University of Maryland, College Park, Maryland

Huggett, R. J., Bender, M. E., Slaan, H. O. (1973). Utilizing metal concentration relationships in the eastern oyster (Crassostrea virginica) to detect heavy metal pollution. Wat. Res. 7: 451-460

Karbe, L., Schnier, C. H., Siewers, H. O. (1977). Trace elements in mussels (Mytilus edulis) from coastal areas of the North Sea and the Baltic. Multielement analyses using instrumental neutron activation analysis. J. radioanalyt. Chem. 37: 927-943

Kingston, H. M., Greenburg, R. R., Beary, E. S., Hardas, B. R., Moody, J. R., Rains, T. C., Liggett, W. S. (1982). The characterization of the Chesapeake Bay: a systematic analysis of toxic trace elements. EPA-79-D-X-0717, U.S. Government, Washington, D.C., p. 1-67

Lobel, P. B., Wright, D. A. (1982a). Relationship between body zinc concentration and allometric growth measurements in the mussel Mytilus edulis. Mar. Biol. 66: 145-150

Lobel, P. B., Wright, D. A. (1982b). Total body zinc concentration and allometric growth ratios in Mytilus edulis collected from different shore levels. Mar. Biol. 66: 231-236

Lobel, P. B., Wright, D. A. (1983). Frequency distribution of zinc in Mytilus edulis (L.). Estuaries 6: 154-159

Manly, R., George, W. O. (1977). The occurrence of some heavy metals in populations of the freshwater mussel Anodonta anatina (L.) from the River Thames. Environ. Pollut. 14: 139-154

Murray, A. J. (1982). Trace metals and organochlorine pesticide and $\mathrm{PCB}$ residues in mussels from England and Wales 1978. Chemy Ecol. 1: 33-45

Phelps, H. L. (1984). A research program in determination of heavy metals in sediments and benthic species in relation to nuclear power plant operation. Final technical report to NASA (Grant No. 09-050-019), 1974-1982, p. 1-82

Phillips, D. J. H. (1976a). The common mussel Mytilus edulis as an indicator of pollution by zinc, cadmium, lead and copper. I. Effects of environmental variables on uptake of metals. Mar. Biol. 38: 59-69
Phillips, D. J. H. (1976b). The common mussel Mytilus edulis as an indicator of pollution by zinc, cadmium, lead and copper. II. Relationship of metals in the mussel to those discharged by industry. Mar. Biol. 38: 71-80

Phillips, D. J. H. (1977). The common mussel Mytilus edulis as an indicator of trace metals in Scandinavian waters 1. Zinc and cadmium. Mar. Biol. 43: 283-291

Popham, J. D., D'Auria, J. M. (1983). Combined effect of body size, season, and location on trace element levels in mussels (Mytilus edulis). Archs environ. Contam. Toxicol. 12; $1-14$

Roosenburg, W. H. (1969). Greening and copper accumulation in the American oyster, Crassostrea virginica in the vicinity of a steam electric generating station. Chesapeake Sci. 3: 241-252

Shuster, C. N., Pringle, B. H. (1969). Trace metal accumulation by the American oyster, Crassostrea virginica. Proc. natn. Shellf. Ass. 59: 91-103

Simkiss, K., Taylor, M. (1981). Cellular mechanisms of metal ion detoxification and some new indices of pollution. Aquat. Toxicol. 1 : 279-290

Sinex, S. A. (1981). Trace element geochemistry of modern sediments from Chesapeake Bay. Ph. D. thesis, University of Maryland

Sunda, W. G., Engel, D. W., Thuotte, R. M. (1978). Effect of chemical speciation on toxicity of cadmium to grass shrimp, Palaemonetes pugio: importance of free cadmium ion. Environ. Sci. Technol. 12: 409-413

Wright, D. A. (1977). The effect of salinity on cadmium uptake by the tissues of the shore crab Carcinus maenas. J. exp. Biol. 67: 137-146

Wright, D. A., Striegel, D. R. (1984). Trace Metals. In: The Integration and Coordination of the Assessment of the Environmental Impacts of Construction and Operation of the Hart and Miller Islands Containment Facility. Second Interpretive Report (Aug. 1982-Aug. 1983) from Chesapeake Research Consortium to Water Resources Administration, Maryland Dept. of Natural Resources (MPA contract 12339-5), p. 219-320

Zamuda, C. D., Sunda, W. G. (1982). Bioavailability of dissolved copper to the American oyster Crassostrea virginica. I. Importance of chemical speciation. Mar Biol. 66: 37-82 